\title{
Infantile digital fibromatosis
}

INSERM

\section{Source}

INSERM. (1999). Orphanet: an online rare disease and orphan drug data base. Infantile digital fibromatosis. ORPHA:199267

Infantile digital fibromatosis is a rare, benign, superficial fibromatosis characterized by firm, pinkish to flesh-colored, solitary or multiple nodular growths, typically less than $2 \mathrm{~cm}$ in size. They occur on the dorsal or lateral aspect of fingers and toes and have a tendency to recur. Histology reveals bland intradermal spindle cells with spherical perinuclear inclusion bodies. 